nearly 1,000 tons gross. On arrival at Billingham the oil, which is made from coal by the coalite process, is being submitted to hydrogenation and converted into about 100,000 gallons of petrol. This is the first time that a bulk consignment of oil obtained by low-temperature carbonisation has been treated by a hydrogenation plant in Great Britain. Tests carried out by Imperial Chemical Industries, Ltd., and H.M. Fuel Research Board show that this oil is particularly suitable for conversion into petrol by hydrogenation, and the event constitutes a notable achievernent in the history of the coal and coal oil industry in Great Britain.

\section{The B.B.C. Annual}

The B.B.C. Annual for 1935 (London: B.B.C. 2s. $6 d$.) is the successor to the B.B.C. Year Book for 1934. This Year Book, after a fairly successful career, has been discontinued. The first section of the Annual gives a history of the Corporation's programme policy for the last five years. The second section is the Corporation's report to the listeners of Great Britain. A report is also given of the activities of the Empire service. We are told that the object is not merely to give a recital of past programmes remembered or forgotten, but to explain and make comments on them. Old problems have to be reconsidered and new problems are always arising. So a new section is started called the 'forum', which is to be a market place for the expression of ideas by authors, who are wholly free and solely responsible for what they write, and is not a pulpit for making pronouncements. It contains some interesting articles discussing amongst other subjects international broadcasting, free speech, music and radio drama. There is also an excellent short obituary notice of the late Mr. J. H. Whitley, who devoted himself during the last years of his life to guiding most successfully the progress of this great national corporation.

\section{Dorothy Temple Cross Research Fellowships}

The Dorothy Temple Cross research fellowships in tuberculosis for the academic year 1935-36 will shortly be awarded by the Medical Research Council, and applications should be lodged with the Council not later than June 1, 1935. The object of these fellowships is to give special opportunities for study and research to persons "intending to devote themselves to the advancement by teaching or research of curative or preventive treatment of tuberculosis in all or any of its forms". Candidates must be British subjects. The fellowships will preferably be awarded to candidates who wish to make their studies or inquiries outside the borders of Great Britain. They will be awarded for one year as a rule, but in special cases may be renewed. The value of the fellowships awarded will depend in each case upon the standing and qualifications of the candidate, but will not be less than $£ 350$ per annum, payable monthly in advance. Travelling and some incidental expenses will be paid in addition. It may also be possible to award a senior fellowship of considerably greater value to a specially well-qualified candidate wishing to undertake an intensive study of some particular problem of tuberculosis at a chosen centre of work in another country. Further particulars and forms of application are obtainable from the Secretary, Medical Research Council, 38 Old Queen Street, Westminster, S.W.1.

\section{Leaflets on Disease of Fruit Trees}

The Ministry of Agriculture has recently issued Collection No. I of Leaflets on Fungus and other Diseases of Fruit Trees, price 1s. 6d, net. This collection contains a copy of each of the leaflets on the subject at present issued by the Ministry, and is bound up in portfolio form so that when a new leaflet or a revised edition of an old one is published an insertion or substitution can readily be made. Sectional vol. 1, which contained the same leaflets in a permanently bound form is, therefore, superseded, as it is hoped that the new arrangement will prove of greater convenience. Those who desire to receive a copy of each new or revised leaflet as it is issued, in order to keep their portfolio up to date, may do so on payment of a nominal annual registration fee. Full particulars concerning this matter may be obtained from the Secretary, Ministry of Agriculture and Fisheries, 10, Whitehall Place, London, S.W.1.

\section{Cultivation of Soft Fruits}

OwING to the imposition of import duties, softfruit growers in Great Britain have been able to find a satisfactory market for home-grown fruit during the past two seasons. The issue of a second edition of Bulletin No. 4, "Soft Fruits", by the Ministry of Agriculture (London : H.M.S.O. 1s. net) will, therefore, be particularly welcomed as it will enable the grower to make the fullest use of his protected position. The principal fruits dealt with in the bulletin remain as before, namely, strawberries, gooseberries, currants, loganberries, raspberries, figs and melons, though the subject matter has been considerably revised. Sections on the cultivation of blackberries and dewberries have, however, been included in the new edition, owing to their increasing popularity. The cultivation of nuts is now omitted, as it is hoped to issue fuller information on nut culture as a separate bulletin.

\section{New Zealand Scenery}

Tur active steps taken by the New Zealand Government to preserve the original scenery of the Dominion are noted in the report on scenery preserva. tion for the year ending March 1934. During the year, more than thirty new reserves were announced. They varied in size from small historic sites to areas of several hundred acres, the largest being about 9,000 acres in the Canterbury district, where a great area of beech bush has been set aside. The total area of scenic reserves in New Zealand is now about a thousand square miles, divided into about as many different parts. The Act of 1908 under which such area can be dedicated to public care has now been amended to allow of any landowner applying to 
have his land declared a private reserve. This will help to maintain the scenic amenities of New Zealand.

\section{The North-East Passage}

Since Baron A. E. Nordenskiöld in the Vega made the North-East Passage in 1878-79, other ships have followed the same route; but it was not until 1932 that the journey was made in one season. In that year Capt. O. J. Schmidt took the ice-breaker Siberiakov from Archangel to Vladivostok. It is now reported by Science Service that in 1934 the icebreaker Theodor Lütke, commanded by Capt. Nikolaev, went from Vladivostok to Murmansk in eightythree days. It should, however, be noted that heavy ice was encountered, and that the passage would have been impossible for a less powerful vessel. These achievements hold out little prospect for an ordinary unprotected trading vessel making use of the route for through passages.

\section{Study of Malnutrition}

A PUBLIC meeting, organised by the Committee against Malnutrition, will be held at the Conway Hall, Red Lion Square, London, W.C.1, on Thursday, May 16, at 8 p.m., to consider the health and nutrition of women and children in Great Britain. The chair will be taken by Prof. V. H. Mottram, and Miss Eleanor Rathbone, M.P., Dr. Janet Vaughan, and Prof. Marrack will be among the speakers. Tickets at $1 s$. each can be obtained from the Honorary Secretary, Mr. F. le Gros Clark, 190 Eagle Street, Holborn, W.C.1. The Committee against Malnutrition, which is a non-party organisation and has been in existence for a little more than a year, was established to obtain information respecting undernourishment among families of unemployed and lowpaid workers, and to co-ordinate efforts towards securing adequate nourishment for all. It publishes a bi-monthly bulletin, and organises propaganda on the subject. The annual subseription is $5 s$.

\section{Announcements}

THE King has been graciously pleased to command that the African Society shall henceforth be known as "The Royal African Society".

Dr. Wallace Ruddell Axkroyd has been appointed by the governing body of the Indian Research Fund Association to the post of director of nutritional research under that Association.

A meting, followed by a discussion, will be held by the British Science Guild in association with the Engineers' Study Circle on Economics, on Thursday, May 16 at 5.30 p.m. in the Lecture Theatre of the Institution of Civil Engineers, Great George Stre日t, S.W.I, when a report on schemes and proposals for economic and social reformswill be presented bylieut.Col.J.V.Delahaye. Tickets (forwhich there isnocharge) are obtainable on application to the Secretary of the British.Science Guild, 6 John Street, Adelphi, W.C.2.

The North East Coast Institution of Engineers and Shipbuilders, Newcastle-on-Tyne, will celebrate the attainment of its jubilee by a series of meetings to be held on July 16-19, in Newcastle-on-Tyne. The celebrations will open with a reception at Armstrong College. On July 17 there will be a meeting to confer honorary fellowships, after which three papers will be read dealing with developments in ship construction during the past fifty years. On July 18 papers on marine engine construction, including turbines, reciprocating steam engines, boilers and heavy oil engines, and on recent progress in electrical and general engineering, are to be read, and on the following day Sir Westcott Abell will deliver a citizens' lecture on "Ships through the Ages".

WE regret that in the article on "Canadian Water Power Developments in 1934", in our issue of April 27, p. 642, it was stated that the investment represented by the present development is estimated at 1,743,000 dollars. This should read $1,743,000,000$ dollars.

"CATtLe IN The Tropics" is the title of a booklet by Prof. Cecil Wood of the Imperial College of Tropical Agriculture, Trinidad (Government Printing Office, Port-of-Spain, 1934). It gives much useful information on the species and breeds of cattle suited to tropical conditions, their utilisation as draught animals and for meat and milk production, harnessing, feeding and general eare, breeding and improvement. Sections are also devoted to their health and the diseases which affect them, and to the organisation of the industry.

ApPLICATIONs are invited for the following appointments, on or before the dates mentioned:-A professor of physiology in University College, Dundee (University of St. Andrews)-The Secretary (May 17). A temporary assistant engineer in the Ministry of Transport-The Establishment Officer, Ministry of Transport, Whitehall Gardens, London, S.W.l (May 17). Chemists for the War Department chemist, Woolwich Arsenal-The Under-Secretary of State (C.5), The War Office, London, S.W.1 (May 18). A secretary to the Advisory Council for Technical Education in South Wales and Monmouthshire-The Advisory Council, County Hall, Cardiff (May 18). A teacher of mechanical engineering and a teacher of electrical engineering in the Schools of Technology, Art and Commerce, Oxford-The Secretary for Education, Education Office, George Street, Oxford (May 20). An animal husbandry expert under the Imperial Council of Agricultural Research, IndiaThe High Commissioner for India, General Department, India House, Aldwych, London, W.C.2 (May 25). A lecturer in mathematics in the Royal Naval College, Greenwich-The Adviser on Education, Admiralty, Whitehall, S.W.1 (May 31). An assistant professor of science in the Indian Institute of Science, Bangalore-The Director (June 1). An assistant inspector of ancient monuments for Wales -The Establishment Officer, H.M. Office of Works, Westminster, London, S.W.1 (June 3). An inspector of agriculture in the Department of Agriculture and Forests, Sudan Government-The Controller, Sudan Government London Office, Wellington House, Buck. ingham Gate, London, S.W.1 (June 10). 